Article

\title{
Ichnofossils, Cracks or Crystals? A Test for Biogenicity of Stick-Like Structures from Vera Rubin Ridge, Mars
}

\author{
Andrea Baucon ${ }^{1, *}$, Carlos Neto De Carvalho ${ }^{2,3}$, Fabrizio Felletti ${ }^{4}$ (D) and Roberto Cabella ${ }^{1}$ (D) \\ 1 DISTAV, University of Genova, Corso Europa 52,16132 Genova, Italy; cabella@dipteris.unige.it \\ 2 Geology Office, Naturtejo UNESCO Global Geopark, Avenida Zona Nova de Expansão, \\ 6060-101 Idanha-a-Nova, Portugal; carlos.praedichnia@gmail.com \\ 3 Instituto D. Luiz, University of Lisbon, Faculdade de Ciências da Universidade de Lisboa, \\ Campo Grande Edifício C1, Piso 1, 1749-016 Lisbon, Portugal \\ 4 Dipartimento di Scienze della Terra 'A. Desio', Università degli Studi di Milano, Via Mangiagalli 34, \\ 20133 Milano, Italy; fabrizio.felletti@unimi.it \\ * Correspondence: andrea@tracemaker.com
}

Received: 8 October 2019; Accepted: 27 December 2019; Published: 21 January 2020

\begin{abstract}
New images from Mars rover Curiosity display millimetric, elongate stick- like structures in the fluvio-lacustrine deposits of Vera Rubin Ridge, the depositional environment of which has been previously acknowledged as habitable. Morphology, size and topology of the structures are yet incompletely known and their biogenicity remains untested. Here we provide the first quantitative description of the Vera Rubin Ridge structures, showing that ichnofossils, i.e., the product of life-substrate interactions, are among their closest morphological analogues. Crystal growth and sedimentary cracking are plausible non-biological genetic processes for the structures, although crystals, desiccation and syneresis cracks do not typically present all the morphological and topological features of the Vera Rubin Ridge structures. Morphological analogy does not necessarily imply biogenicity but, given that none of the available observations falsifies the ichnofossil hypothesis, Vera Rubin Ridge and its sedimentary features are here recognized as a privileged target for astrobiological research.
\end{abstract}

Keywords: palaeontology; ichnology; ichnofossils; pseudofossils; astrobiology; biosignatures; Mars; Vera Rubin Ridge; Gale Crater; Haroldswick

\section{Introduction}

New observations at Vera Rubin Ridge by the Mars Space Laboratory Rover Curiosity show millimetric, elongate structures preserved in sedimentary rocks deposited in fluvio-lacustrine environments within Gale Crater. On Earth, such settings are inhabited by an enormous diversity of macro- and microorganisms producing traces of life-substrate interactions $[1,2]$ that are similar to the structures of Vera Rubin Ridge.

Ever since they were announced, the structures from Vera Rubin Ridge have been controversial. In a blog post, NASA scientists labelled the structures as enigmatic stick-like features, proposing an abiotic origin as erosion-resistant mineral veins [3]. By contrast, DiGregorio [4] suggested a potential biogenic nature as the fossilized products of life-substrate interactions (ichnofossils). This biogenic hypothesis was informally disputed in a set of blog posts including interviews of Earth and planetary scientists [5-7]. Despite of this debate, morphology, size and topology of the stick-like structures are yet incompletely known, and their potential biogenicity remains untested. To date, there is no peer-reviewed paper discussing the abiotic hypothesis for the stick-like structures. In this paper we 
aim to fill these gaps by testing their biogenicity. Accordingly, the null hypothesis is that the observed features are abiotic in origin; the alternative hypothesis is that their origin is biological.

All the structures that we describe here come from the rock target Haroldswick, which is located on the northern foothill of Aeolis Mons (Mt. Sharp) at Vera Rubin Ridge, within Gale Crater. Vera Rubin Ridge is an elevated crest, $250 \mathrm{~m}$ wide, on Aeolis Mons [8,9]. It is characterized by a hematite signature in spectra, for which reason it is also known as Hematite Ridge $[9,10]$. The Vera Rubin Ridge consists of Murray formation deposits that experienced enhanced cementation resulting in its preservation as a ridge [11]. Understanding the origin of the ridge has been a key objective for the Mars Science Laboratory mission since before landing [12]. Vera Rubin Ridge has been recognized as an iron-bearing environment appropriate for biosignature preservation [13].

The stick-like structures have been imaged by the Mars Science Laboratory rover Curiosity during Martian days (Sols) 1905, 1921 and 1923. Their host rock pertains to the fluvio-lacustrine Murray Formation, which is evidence of the presence of ancient lakes in the Gale crater and indicates the existence of habitable environments between $\sim 3.8$ billion and 3.1 billion years ago [14-18] (for a geological overview, see also $[16,17,19,20])$.

\section{Materials and Methods}

Source images have been acquired by rover Curiosity using (1) Mastcam during Martian days (Sols) 1905 and 1921, (2) ChemCam on Sol 1921, (3) Mars Hand Lens Imager (MAHLI) on Sols 1922 and 1923. Images with stick-like structures have been analysed with the image analysis software Fiji 1.51 $\mathrm{w}$ (http://fiji.sc), an image processing package based on ImageJ. Results of width, length and angle analysis are listed in the Appendix A, Figures A1-A3 and Tables A1-A3. Size of the structures have been derived from source images using the MAHLI equations [21].

\section{Results}

11 stick-like structures are preserved as erosion-enhanced reliefs within a siltstone outcrop (Figure 1: specimens s1 to s11). They consist of horizontal, straight segments that are frequently connected by curved turns (Figure 2a). Structures are unlined. Contact with the host rock is sharp, but there are no manifest grain-size differences between the stick-like structures and the host rock. Our investigations using image analysis and MAHLI equations [21] show an average width of $0.7 \mathrm{~mm}$. The ends of few structures (s1, s11) appear tapered but it is unclear whether tapering results from primary (i.e., structure-producing) or secondary (e.g., weathering, fragmentation) processes; as such, ends of these structures have been excluded from image analysis. Accordingly, each structure retains a constant width along its length (average per-specimen variation in width: $0.1 \mathrm{~mm}$ ). Widths tend to be constant also between structures (width range: $0.5-0.9 \mathrm{~mm}$ ). Results of image analysis show an average length of $4 \mathrm{~mm}$, but this value underestimates the original length because stick-like structures show clear evidence of fragmentation (Figure 2a). Some of the structures intersect (specimens s4-s5; s8-s9; s10-s11; Figure 2a-c) or coalesce without intersecting (structures s1-s5; Figure 2a). Average intersection angle is $63.1^{\circ}$. See Appendix A for additional information about morphometric analysis (Figures A1-A3, Tables A1-A3). 


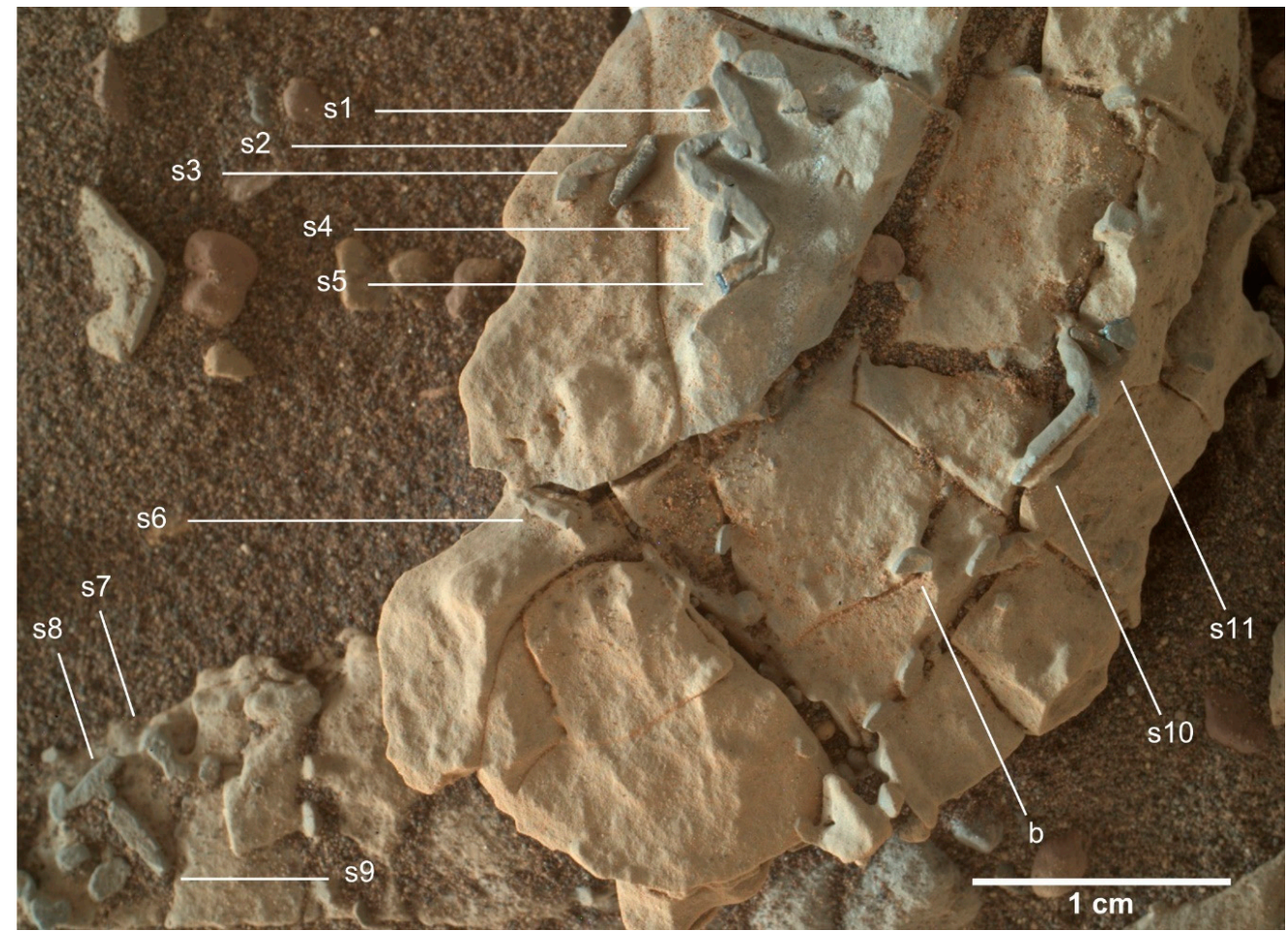

Figure 1. The stick-like structures at Vera Rubin Ridge, Mars. Labels indicate individual specimens of stick-like structures (s1-s11) and bulbous structures (b). Outcrop imaged by rover Curiosity using MAHLI (image 1922MH0001520010703174C00_DXXX).
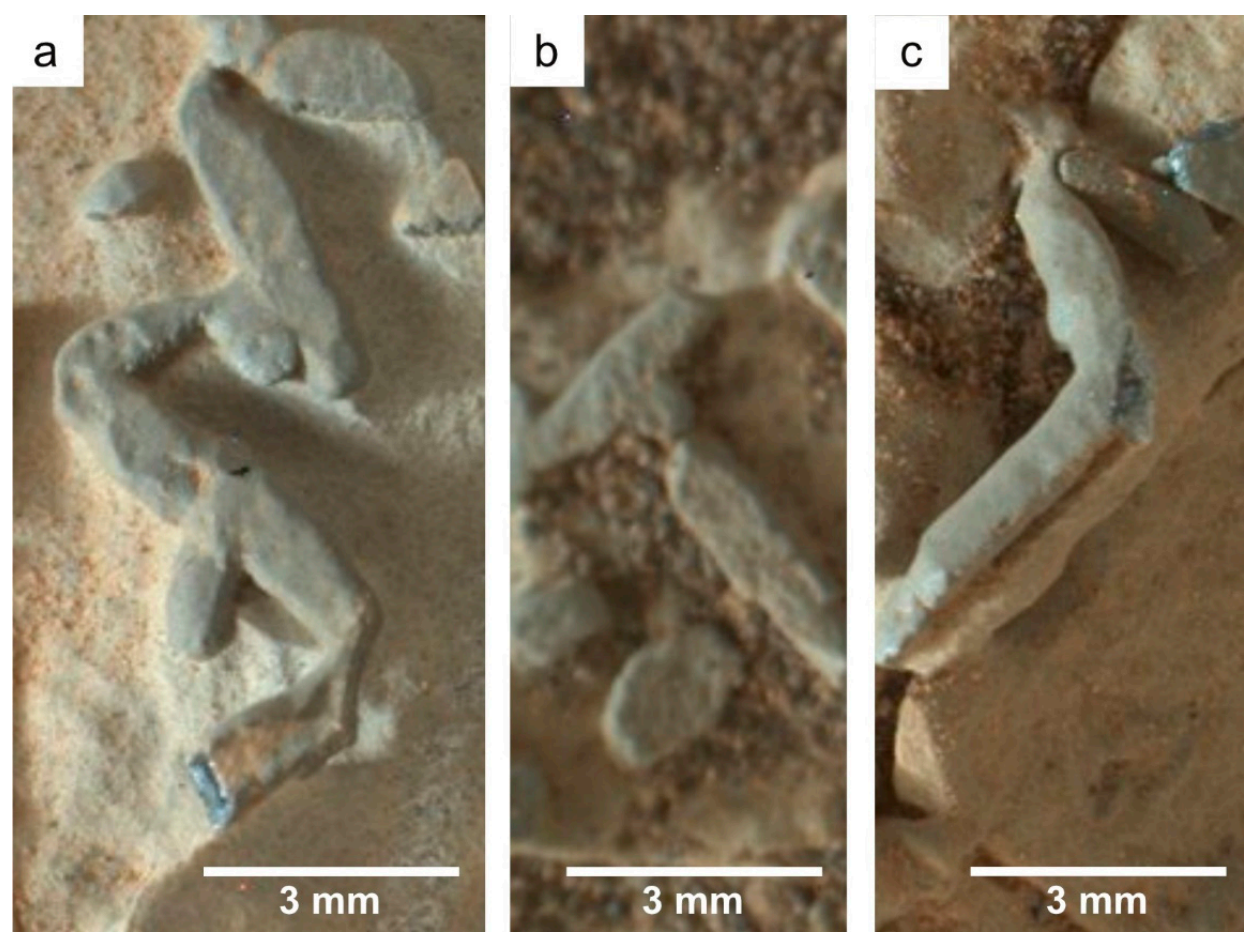

Figure 2. Stick-like structures from Mars. (a) Stick-like structure s4 intersecting the S-shaped form s5, which changes its curvature at short distance from specimen s1. (b) T-junction formed by specimens s8 and s9. (c) Intersection between specimens s10 and s11. See Figure 1 for specimen numbers. 


\section{Discussion}

In order to test the null hypothesis (abiotic origin), the stick-like structures are compared with similar non-biological structures found on Earth and known to occur on Mars, according to their (a) morphology, (b) size, (c) geological context and (d) topological interrelationships.

The morphological features of the stick-like structures are shared with crack fills. Desiccation cracks are a common component of continental deposits on Earth (Figure 3a), whereas they have been reported on Mars from the Murray Formation [14] and Meridiani Planum [22]. Martian desiccation cracks meet orthogonally, forming T-junctions [14]; this compares favourably with the T-junction observed in a pair of stick-like structures (s8, s9; Figure 2b). Subaqueous sedimentary cracks, also known as synaeresis cracks or intrastratal shrinkage cracks [23,24], have been documented on Mars in the Sheepbed mudstone [25]. Similarly to the Vera Rubin Ridge structures, subaqueous sedimentary cracks can form incomplete polygons consisting of curved (curlicue-like; Figure 3b), at times branched elements; unlike the stick-like structures, they are usually spindle-shaped and can present tapered tips [23] (Figure 3b-d). On Earth tapering is an important feature of ichnofossil-like structures because it argues against an ichnological origin [26]. Most of the Vera Rubin Ridge structures are not tapered; the only exception is represented by specimens s1 and s11, but it is unclear whether their narrow tips resulted from primary (i.e., structure-producing) or secondary (e.g., weathering, fragmentation) processes.
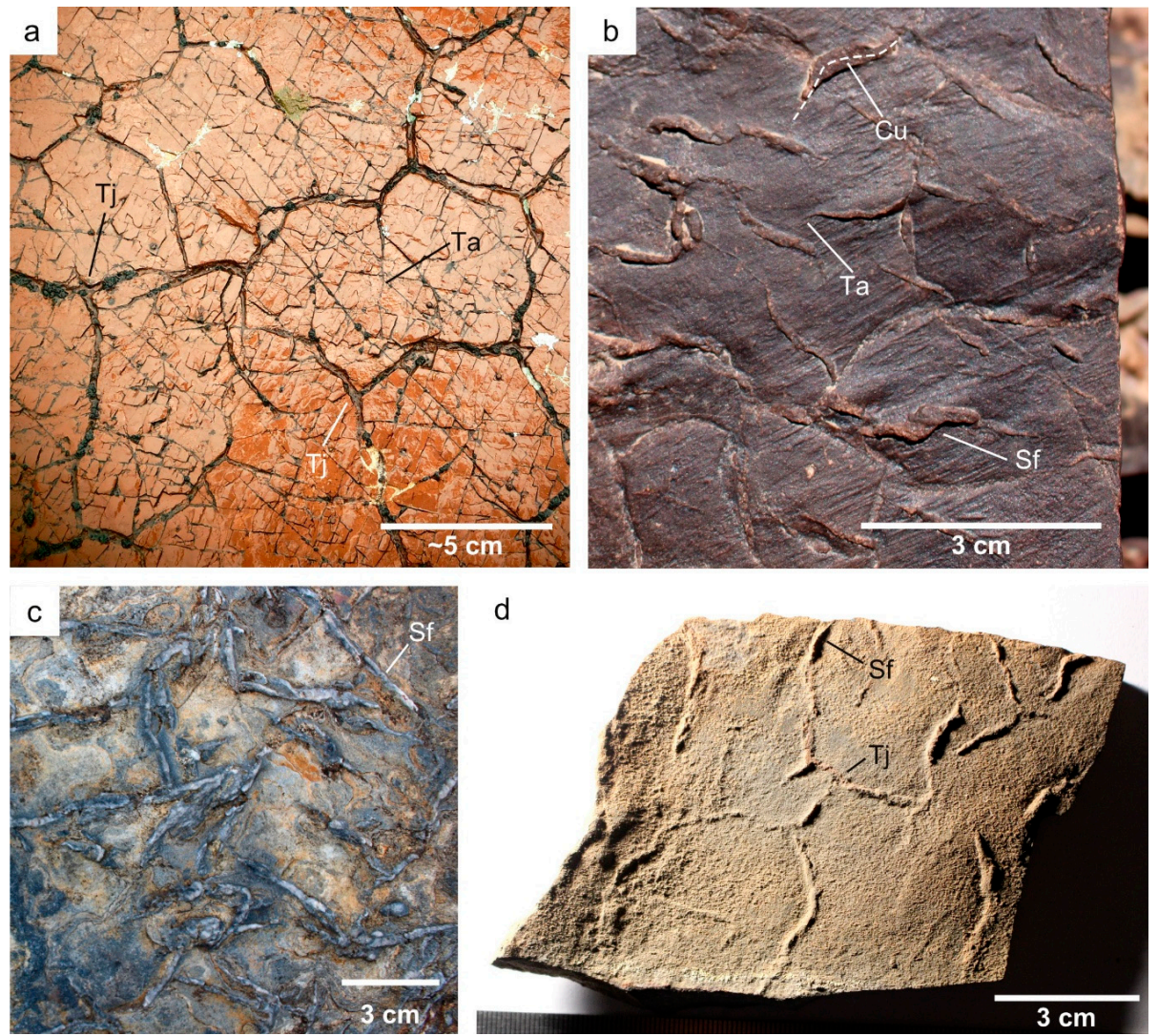

Figure 3. Sedimentary cracks and their salient features. (a) Mud cracks showing tapering (Ta) and T-junctions (Tj). Gorges de Daluis, France (Permian). (b) Shrinkage cracks with curved shape (Cu), tapered edges (Ta) and steep flanks (Sf). Kalshaneh section, Tabas, Central Iran (Lalun Fm., Lower Cambrian). (c) Shrinkage cracks with steep flanks (Sf). Vale da Mua section, Portugal (Armorican Quartzite Formation, Lower Ordovician). (d) Shrinkage cracks with steep flanks (Sf) and T-junctions (Tj). Penha Garcia Ichnological Park, Portugal (Lower-to-Middle Ordovician). 
The commonly steep flanks of the stick-like structures (Figure 2a-c) are consistent with crack fills (Figure $3 b-d)$. Because of morphological similarities and geological context, sedimentary cracks are a plausible analogue for the stick-like structures. On Earth, formation of cracks is commonly mediated by microbial mats, whereas on Mars cracks are associated to structures resembling microbialites [27]. It should be however noted that abiotic processes can explain the production of cracks $[23,24]$.

Non-sedimentary cracking is an additional candidate process to explain the stick-like structures because of the abundant fractures observed on Mars, where sulfate-mineralized fractures attributed to hydraulic fracturing are found in the Murray [14] and Yellowknife Bay formations [16]. The immediate surroundings of the stick-like structures show abundant non-sedimentary cracks, but their size, lack of fill and orientation are markedly different with respect to the stick-like structures. Filled fractures can also be rejected because of their typical tabular shape, whereas stick-like structures are roughly prismatic. Tension gashes are also excluded because they have tapered ends and because they tend to form conjugate sets.

The stick-like structures might be explained as single mineral crystals because of their elongate shape, the commonly polygonal cross-section and the flat faces meeting at $\sim 90^{\circ}$. These features are shared, for instance, with gypsum crystals grown in sabkha environments on Earth (Figure 4a,b; see also Figures 9a and 11a in [28]). Cross-cutting between s4 and s5 reminds of penetration twinning, i.e., the process by which minerals intergrow and result in interpenetrating individuals [29]. Curved morphology of the stick-like structures does not disprove the null (abiotic) hypothesis since curved, needle-like gypsum crystals of comparable size have been reported from terrestrial evaporitic settings [30,31]. Sulfate minerals, including gypsum, have been documented on the Martian surface with data from satellites, landers, and rovers [32]. Among other processes, curvature of millimetre-sized gypsum crystals can result from impurity incorporation followed by crack formation and mechanical twinning [33]. Nevertheless, euhedral monocrystals and their pseudomorphs are not perfect analogues of the stick-like structures. In fact, the tips of most stick-like structures do not show the smooth flat faces and the sharp crystal-like outlines that typify euhedral monocrystals [29] and their pseudomorphs (Figure 4c,d). It should be noted that tips of specimens s4-s6 are smooth and flat, but they could reflect secondary (i.e., fragmentation) processes. In addition, cleavage is not detectable. For instance, there is no evidence of the easy (010) perfect cleavage that is typical of gypsum and anhydrite [29] (Figure 4a).

Tectographs, i.e., pseudofossils produced by the movement of rock layers relative to each other [34], can be rejected as an explanation for the Vera Rubin Ridge structures because the stick-like features are not parallel between each other. 

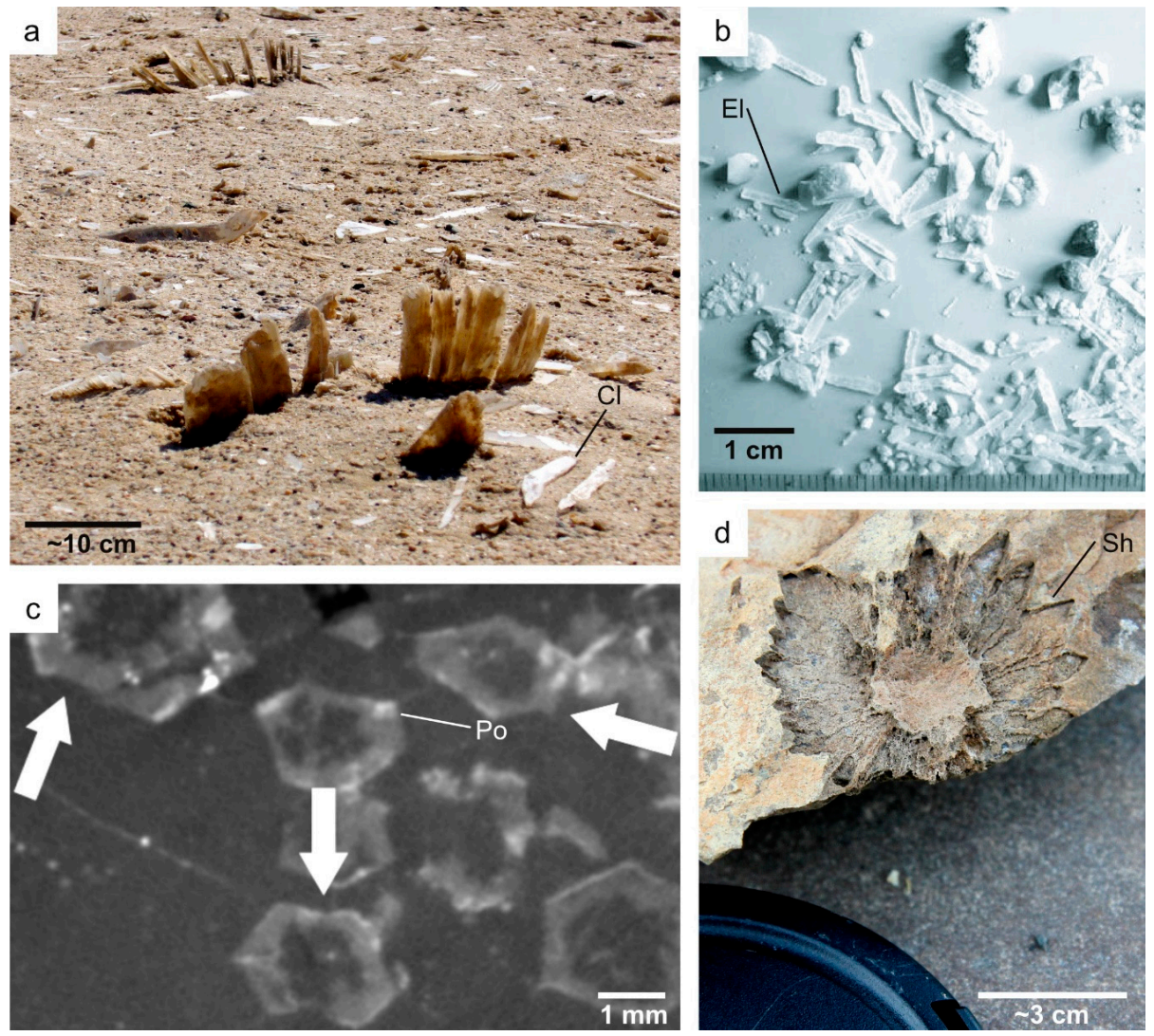

Figure 4. Crystals and crystal pseudomorphs. (a) Exhumed large gypsum crystals from sabkha deposits. Crystals shows an elongate shape and the tendency to split along definite planes of weakness (cleavage: $\mathrm{Cl}$ ). Gypsum crystals formed earlier than those developing today. Sabkha of Barr Al Hikman, Sultanate of Oman. Larger crystals are $12 \mathrm{~cm}$ long. Image from [35]. (b) Nest of fibrous gypsum crystals 10-20 cm below the sabkha surface. Gypsum crystals show an elongate shape (El). Sabkha of Barr Al Hikman, Sultanate of Oman. Image from [35]. (c) Computed tomography scan (CT-scan) of crystal pseudomorphs. Crystals show a polygonal cross-section (Po). Large arrows show pointed spurs close to some vertices, which are a typical feature of aragonite contact twins. 3.48 Ga-old Dresser Formation (Pilbara Craton, Australia). Image from [36]. (d) Glendonite moulds from the shallow marine Rurikfjellet Formation [37] showing sharp contact with the host rock (Sh). Early Cretaceous of Svalbard.

Although the null hypothesis (abiotic origin) cannot be readily disproved, it should be noted that the morphology of the stick-like structures resembles that of horizontal burrows such as Helminthoidichnites (Figure 5a) and Planolites, which are common components of fluvio-lacustrine settings on Earth [38-40]. Constant width is a typical feature of burrows on Earth (Figure 5a-d) since tracemakers tend to minimize energy expenditure, producing burrows as wide as their width [41]. Stick-like structures are within the size and shape range of ichnofossils on Earth (see Figure 5). Most specimens from Vera Rubin Ridge present polygonal cross-sections, as suggested by fragmented specimens and the prevailingly flat upper surfaces (Figure 2a-c). Polygonal cross-section is apparently non-adaptive for burrowing behaviour, but there are few examples of ichnofossils on Earth with squarish sections, e.g., Arthrophycus [42], (Figure 5e,f) Bulbichnnus [43] and Oblongichnus. Subcylindrical specimens with roughly elliptical cross-section are also found (e.g., s2), although they are rarer than polygonal ones. 

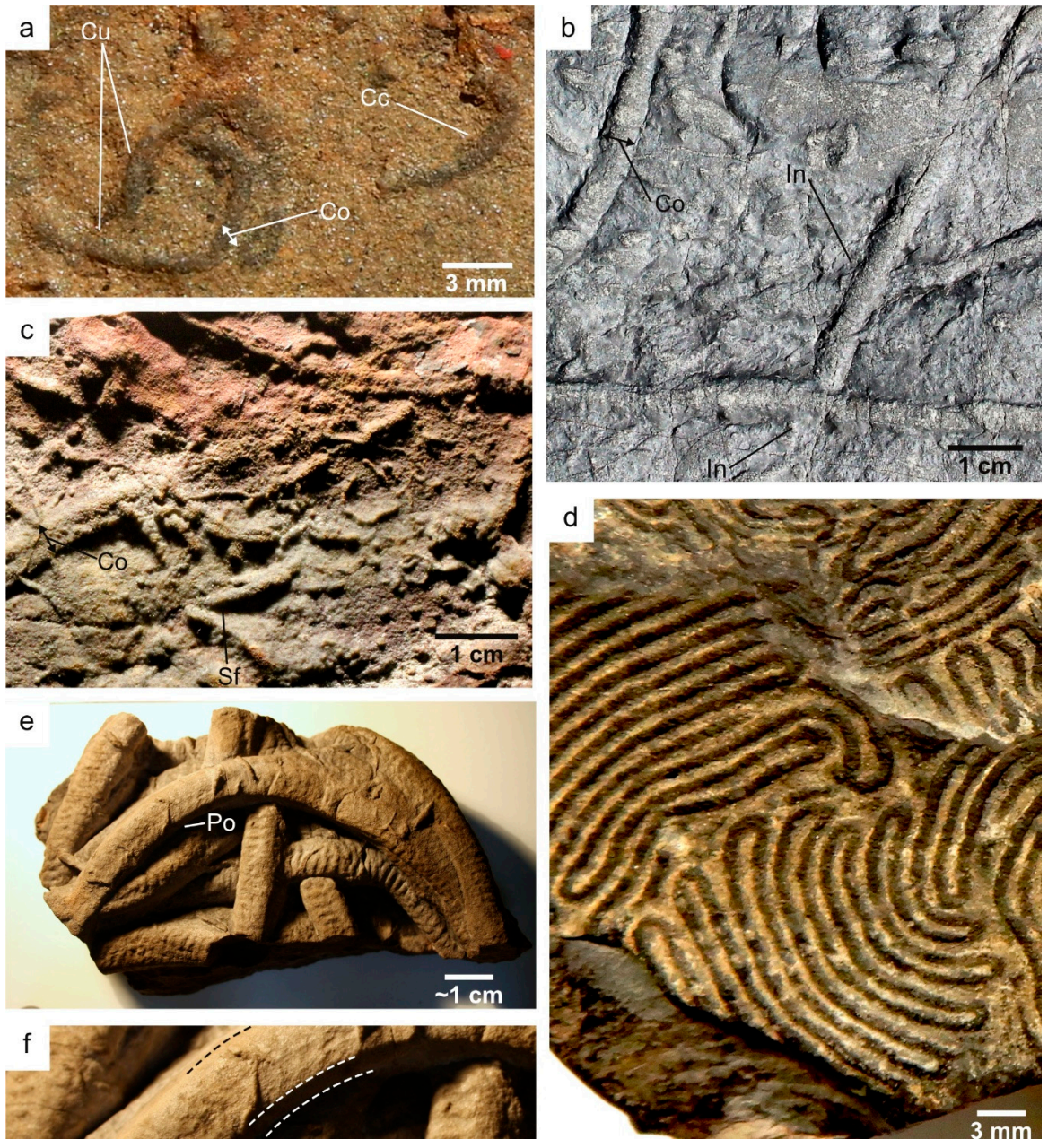
Figure 5. Ichnofossils and their salient features. (a) Fossil burrows (Helminthoidichnites) showing
constant width $(\mathrm{Co})$, curved morphology $(\mathrm{Cu})$ and color contrast with the host rock (Cc). Upper Carboniferous of the Pramollo Basin, Italy-Austria [39,40]. (b) Fossil burrows (Taenidium isp.) displaying constant width (Co) and intersections (In). Corte Pereiro section, Toca da Moura Complex, Ossa-Morena Zone in southern Portugal (Carboniferous: Mississipian). (c) Helminthoidichnites and Cruziana problematica displaying constant width (Co) and steep flanks (Sf). Ichnological Park of Penha Garcia, Portugal (Ordovician). (d) Nereites (=Helminthoida) irregularis showing constant width and thigmotaxis, i.e., a behaviour according to which an organism stays close to an existing entity. Piani di Creto, Italy (Cretaceous). Specimen 24175/TF16 of the University of Genova. (e) Arthrophycus alleghaniensis displaying polygonal, squarirsh cross-section (Po). Mação, Portugal (Lower Ordovician). Specimen 13,184 of the Geological Museum of Lisbon [44]. (f) Detail of the square cross-section (dashed lines) of Arthrophycus alleghaniensis. The magnified area is indicated by Po in Figure 5e.

Most stick-like structures do not geometrically interact with each other, but some pairs are coalescing and intersecting. A prominent example consists of a S-shaped structure (s5) that abruptly changes its curvature at short distance from another stick-like feature (s1), staying in close contact with it but without intersecting (Figure 2a). This indicates that the development of stick-like structures can be influenced by existing (syngenetic) ones. On Earth, this is a typical outcome of taxes, i.e., the orientation and turning of an organism in response to a perceived external stimulus field [45]. Similarly to the ichnotaxa Helminthoidichnites (Figure 5a), Helminthorhaphe and Nereites (=Helminthoida) irregularis (Figure 5d), the S-shaped structure from Vera Rubin Ridge can be modelled by using a thigmotaxis rule, compelling an agent to stay close to an existing entity [46,47]. Nevertheless, evaporitic minerals can grow very rapidly, hence we expect that a crystal can act as a physical constraint for the growth 
of successive, almost syngenetical, ones. This phenomenon could replicate thigmotaxis behaviour, posing significant problems in disproving the null (abiotic) hypothesis.

Soft-sediment deformation, fluid escaping and sedimentary cracking may account for the genesis of ichnofossil-like sedimentary structures [48] but such abiotic explanations of the observed thigmotaxis-like topological relationship are difficult to prove for those processes. Vertical fluid escape can produce tiny vertical tubes (pillars) slicing steeply through massive or laminated sand [49]. Alternatively, sand-filled fractures (sand dykes), commonly rooted in a structureless sand bed, can be formed by the introduction of material from above, either under pressure or by simple filling of pre-existing cracks or fissures. Sand dykes are straight to sinuous in vertical view; their sinuosity can be increased by post-depositional compaction, with the development of ptygmatic folds [50]. However, these processes are not known to produce the topological relationships observed in Martian specimens. Similarly, to our knowledge there are no examples of sedimentary cracks that change their curvature when encountering others.

The S-shaped structure is cross-cut by another stick-like feature (Figure 1: s4), showing that the here studied structures can also intersect during their development. This feature is shared with ichnofossils (Figure 5b). Active displacement of sediment, including cross-cutting, is considered a strong indicator of an ichnological nature for terrestrial structures [26]. It should be however noted that cross-cutting is also shared with cracks and syngenetical crystal intergrowth. Our image analysis reveals an average intersection angle of $63.1^{\circ}$ (intersection angle range: $39.8^{\circ}-85.6^{\circ}$ ). Some of the Vera Rubin Ridge structures present angular terminations (e.g., s5), which is expected from breakage of an organism with a modular growth [26]. Similar size of different structures and sinuous orientation are also compatible with body fossils of flexible organisms, which however cannot be preserved as cross-cutting structures. Cross-cutting precludes the hypothesis of stick-like structures as body fossils. In addition, carbonized remains, which are a criterion for recognizing the body fossil origin of sedimentary structures [26], are not documented from the Vera Rubin Ridge structures.

The stick-shaped features are unlined; contact with the host rock is sharp and well-defined, although there is apparently no difference in grain-size between the stick-like structures and the host rock. Sharp contacts, and the elevation of the stick-like structures relative to the host rock, suggest that the host rock weathered at a faster rate than the stick-like structures (differential weathering). Hence, the stick-like structures are likely to be more resistant than the host rock, possibly because of more intense cementation. Resistance to erosion is confirmed by the presence of an isolated fragment (Figure 1: s2) that experienced short-distance transport.

Stick-like structures from Vera Rubin Ridge are darker-toned than the altered host rock but show similar hues with respect to the unaltered substrate. Unlike the substrate, broken segments often display metallic hues ( 55 in Figures 1 and 2a). This does not preclude an ichnological origin of the stick-like structures because ichnofossils with metallic hues can result from early diagenetic processes, e.g., on Earth pyrite and barite-filled burrows have been documented from a variety of depositional settings, including postglacial lacustrine clays [51,52]. The stick-like structures are found over an area of approximately $15 \mathrm{~cm}^{2}$. Such clustered distribution implies that the processes responsible for the development and/or preservation of the structures should have been active locally. This is compatible with biotic processes, e.g., on Earth stressed environments are characterized by low diversity assemblages [53] with uneven distribution of ichnofossils [54,55]. However, this does not preclude an abiotic origin for the stick-like structures. For instance, in sedimentary rocks, crystals may grow in aggregates depending on the unevenly high concentration of dissolved ions.

The stick-like structures occur in a geological context that fits with evaporitic crystals and sedimentary cracks. The geological context also fits with the accepted criteria for the identification of ichnofossils on Earth [56], i.e., they are syngenetic with the primary fabric of the host rock which is sedimentary and well understood in the regional geological context of Gale Crater; stick-like structures are cross cut by later stage fractures and are filled with material capable to survive to the diagenetic history of the rocks. In addition, stick-like structures are related to an ancient habitable 
environment [14-18]. Bulbous structures (e.g., structure b in Figure 1) are embedded in the host rock of the stick-like structures. They are here interpreted as concretions, intended as confined bodies of clastic sediment lithified by authigenic minerals [57]. On Earth, formation of concretions is commonly mediated by biogenic processes such as microbial activity and the presence of organic matter-including mucus on burrow walls [58] — but fully abiotic processes can also explain the origin of some concretions [59]. Nevertheless, to our knowledge there are no examples of abiotic concretions sharing the main morphological features of the stick-like structures, which are roughly polygonal shape, with constant width and curved orientation. On Earth, curved burrows represent the main physicochemical setting for the development of curved concretions [58]. There are no conclusive evidences showing a common origin of the concretions from Haroldswick and the stick-like structures. In fact, concretions share a similar texture, size and colour with the stick-like structures, but they lack the metallic hues that are sometimes observed in stick-like structures. In addition, they differ from the stick-like structures in having a predominantly elliptical cross section with a larger size (major axis is typically $\sim 1.5 \mathrm{~mm}$ ). Other post-depositional structures within the Murray Formation include enhanced relief features, dark raised-ridges and veins [60]. Among these, enhanced relief features share several features with the stick-like structures of Haroldswick, i.e., they are embedded in the host rock, show topographic relief above the surface, they are not clearly related to fracture patterns, they are darker than the altered host rock [60]. Unlike the stick-like structures, enhanced relief features tend to be dendritic, their width is not constant and, most important of all, the contacts with the host rock show no evidence of distinct boundaries.

The hypothesis-testing approach we applied finds a strong parallel in the protocol proposed by Brasier and Wacey [61,62] for demonstrating biogenicity of candidate body fossils and stromatolites. Following this approach, candidate fossil structures should not be accepted as of biological origin until all plausible explanations of their non-biological origin have been tested and falsified, that is, until the null hypothesis of an abiogenic origin is rejected. Our results show that none of the plausible non-biological explanations of the stick-like structures is fully satisfactory. It may be therefore tempting to claim the biogenicity of the stick-like structures, also because none of the available observations falsifies an eventual ichnofossil origin of them.

Nevertheless, our results do not allow to claim the biogenicity of the stick-like structures. In fact, available evidence cannot disprove the null hypothesis, that is, the abiotic nature of the stick-like structures. Carl Sagan's tenet ("Extraordinary claims require extraordinary evidence"; [63]) does not only suggest caution when interpreting extraterrestrial ichnofossil-like structures, but it also encourages the search for extraordinary evidence (e.g., regularly meandering ichnofossils) on Mars.

In sum, our observations do not necessarily imply that the stick-like structures are biogenic but, given that none of the available observations at Vera Rubin Ridge falsifies their ichnofossil origin, the stick-like structures are here identified as a privileged target for astrobiological research. As such, the stick-like structures from Vera Rubin Ridge follow the recommendation of NASA's Mars 2020 Science Definition Team [64] in that they might have a biological origin and thus compel researchers to gather more data before reaching a conclusion as to the presence or absence of past life (see also [65]).

Our results also highlight the urgent need of establishing a robust set of quantitative criteria for demonstrating the biogenicity of ichnofossil-like structures, microscopic and macroscopic. In other words, there is the need of defining the morphospace of ichnofossils and abiogenic ichnofossil-like structures. This will allow to reject the null hypothesis of an abiogenic origin for candidate ichnofossils via morphospace analysis. This clearly parallels the cell morphospace approach [61].

The establishment of biogenicity criteria would benefit not only the search for extraterrestrial life, but also the search for Precambrian life on Earth. In fact, the Precambrian geological record comprises several problematic structures that have been rejected as trace fossils and reinterpreted as either abiogenic structures or body fossils in some cases [26,66]. Ichnofossil-like pseudofossils have also been recognized in more recent deposits [67]. A metazoan-like bodyplan is not essential for producing macroscopic traces, as evidenced by microbial-related structures in Ordovician low-oxygen 
environments [68]. Microorganisms can even produce macroscopic trails or burrows, as evidenced by $2.1 \mathrm{Ga}$ ichnofossils attributed to multicellular or syncytial organism able to migrate laterally and vertically [69]. These non-metazoan macroscopic ichnofossils encourage research of extraterrestrial analogues, i.e., ichnofossils produced by the aggregation of amoeboid cells into a motile slug-like phase, similar to that of terrestrial slime molds.

In addition, five properties of ichnofossils highlight the astrobiological potential of these biogenic structures and therefore encourage the establishment of biogenicity criteria for ichnofossil-like structures [70]. First, they preserve the activity of soft-bodied (e.g., [71]) or poorly mineralized (e.g., [72]) organisms, together with skeletonized forms. Second, they are resilient to processes that obliterate other biosignatures, as evidenced by trace fossils preserved in metamorphosed and highly tectonized rocks [73-75]. Because of their preservation potential and abundance, ichnofossils are among the most abundant evidence of microscopic and macroscopic past life, as exemplified by 3.7 billion-years-old stromatolites [76], 2.1 billion-years-old burrows [69], and ca. 551 million-years-old trackways [77]. Third, they are very visible biosignatures, either because they tend to be enhanced by diagenesis [78] or by the effects of tracemaking itself [79]. Fourth, the morphology of ichnofossils often reflect environmental conditions at the time of deposition [80]. Fifth, ichnofossils are not only direct evidence of biological behaviour [81,82], but their morphology is commonly independent from the morphology, size and biochemistry of the tracemaker. Since that extraterrestrial life may differ significantly from the one on Earth in morphology, size and biochemistry, ichnofossils are biosignatures that are ideally suited for detecting any type of life [70]. These properties show the astrobiological potential of ichnofossils, hence establishing biogenicity criteria would be of fundamental help for the search of extraterrestrial life and of early life on Earth.

\section{Conclusions}

The new observational and morphometric data reported here have far-reaching implications for the search of extraterrestrial life. Our morphometric and topologic data are unique to the stick-like structures among Martian geological features and show that ichnofossils are among the closest morphological analogues of these unique features.

In fact, the stick-like structures show morphological (elongate shape; presence of curves; constant width; clustered distribution) and topological (cross-cutting, coalescing relationships) features that are commonly observed in ichnofossils (Table 1). Geological context and size are also compatible with ichnofossils. By contrast, steep flanks and the somewhat polygonal cross-section are rarely observed in ichnofossils on Earth, with few exceptions (Arthrophycus, Oblongichnus, Bulbichnus).

Following the interpretation of other extraterrestrial biogenic-like structures [65], the absence of unequivocal evidence for life on Mars is the only evidence that favours an abiotic origin of the stick-like structures. Nevertheless, available data cannot fully disprove two major abiotic hypotheses, that are sedimentary cracking and evaporitic crystal growth as genetic processes for the structures. The polygonal section and the steep flanks support the crystal hypothesis, although the stick-like structures lack the smooth flat faces and the sharp crystal-like outlines that typify the tips of euhedral monocrystals. The T-junctions and incomplete polygons formed by the stick-like structures remind of filled sedimentary cracks, although shrinkage cracks, unlike the stick-like structures, are usually spindle-shaped and can present tapered tips (Table 1). Accordingly, the available observations at Vera Rubin Ridge do not allow to claim the biogenicity of the stick-like structures, but they encourage the collection of further data, especially geochemical, about this kind of sedimentary structures on Mars.

Consequently, this case study raises the question of how to disprove the abiotic origin of an ichnofossil-like structure in ancient sedimentary deposits on Earth and beyond. The answer to this question necessarily lies in the study of morphology and geological context, since the chemical composition of passively-filled ichnofossils is not necessarily related to biologic processes. This question, and its converse (how to prove biogenicity of ichnofossil-like structures) are of fundamental importance not only because ichnofossils are the most persistent macroscopic evidence for life on Earth, but also 
because they are independent from morphology, size and biochemistry of the producer. As such, ichnofossils would allow to recognize life that differs from known - terrestrial - life. By describing the unique Vera Rubin Ridge structures from Mars, this study emphasizes the potential of ichnology as a new frontier in astrobiology.

Table 1. Characteristics of the stick-like structures and their occurrence in their closest morphological analogues. Five occurrence classes are used (from the most frequent to the less frequent: always, usually, often, rarely, never). Color scale reflects frequency of occurrence.

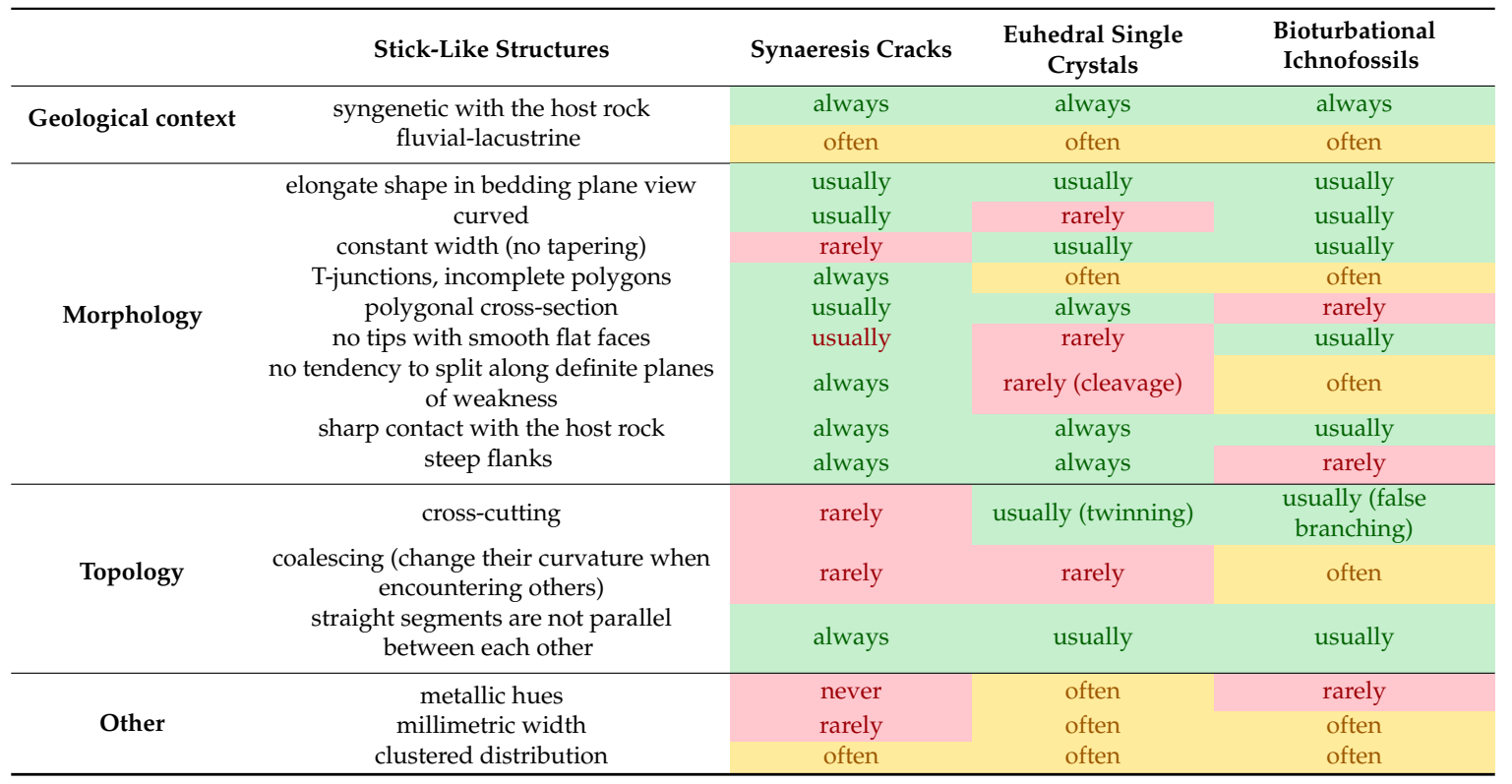

Author Contributions: Conceptualization, A.B.; Data curation, A.B., C.N.D.C., F.F. and R.C.; Formal analysis, A.B., C.N.D.C., F.F. and R.C.; Funding acquisition, A.B.; Investigation, A.B., C.N.D.C., F.F. and R.C.; Methodology, A.B.; Project administration, A.B.; Supervision, A.B.; Validation, A.B.; Visualization, A.B.; Writing-original draft, A.B.; Writing-review \& editing, A.B., C.N.D.C., F.F. and R.C. All authors have read and agreed to the published version of the manuscript.

Funding: The work of A.B. has been supported by the UNIVERSITY OF GENOVA, projects ALAN-X, PALEOGIANTS, CURIOSITY.

Acknowledgments: Two anonymous reviewers are thanked for their constructive comments which greatly improved the paper. Derek Burgess (Martin Marietta, Raleigh, NC, USA) and David Loope (University of Nebraska-Lincoln, Lincoln, NE, USA) is thanked for discussion on concretions. We thank Barry di Gregorio (University of Buckingam, Buckingham, UK) for discussion on the biogenicity of the structures and we acknowledge him as the first to make the parallel between ichnofossils and the stick-like structures. Lorenzo Bonini, Angelo De Min, Romana Melis, Stefano Furlani, Maurizio Ponton, Francesco Princivalle, Nevio Pugliese (University of Trieste, Trieste, Italy) are thanked for discussion on the morphology of the structures. Six anonymous reviewers are thanked for revising a preliminary version of the manuscript. Aram Bayet-Goll (IASBS of Zanjan, Zanjan, Iran) coordinated the fieldwork in Iran; Gil Machado (Inst. D. Luiz, Lisbon, Portugal) and Noel Moreira (Univ. Évora, Évora, Portugal), as well as Sebastião Fraústo, are warmly thanked for the location of Corte Pereiro and Vale da Mua sections, respectively. The authors greatly appreciate the access to the collections of the Geological Museum of Lisbon, especially to its executive director Miguel Ramalho. Monique Mettraux (Geosolutions, Pau, France) and Elias Samanakassou (IAS, University of Geneva, Geneva, Switzerland) are thanked for providing pictures of evaporite crystals (Figure 4a,b). Juan Manuel García-Ruiz (CSIC, Universidad de Granada, Granada, Spain) is thanked for providing a pseudomorph picture (Figure 4c). Madeline Vickers (University of Copenaghen, Copenaghen, Denmark) is acknowledged for providing a glendonite picture (Figure 4d). Alexander E.S. Van Driessche (ISTerre-CNRS \& Univ. Grenoble Alpes) and Maciej Babel (University of Warsaw, Warsaw, Poland) are thanked for crystal images.

Conflicts of Interest: The authors declare no conflict of interest. 


\section{Appendix A}

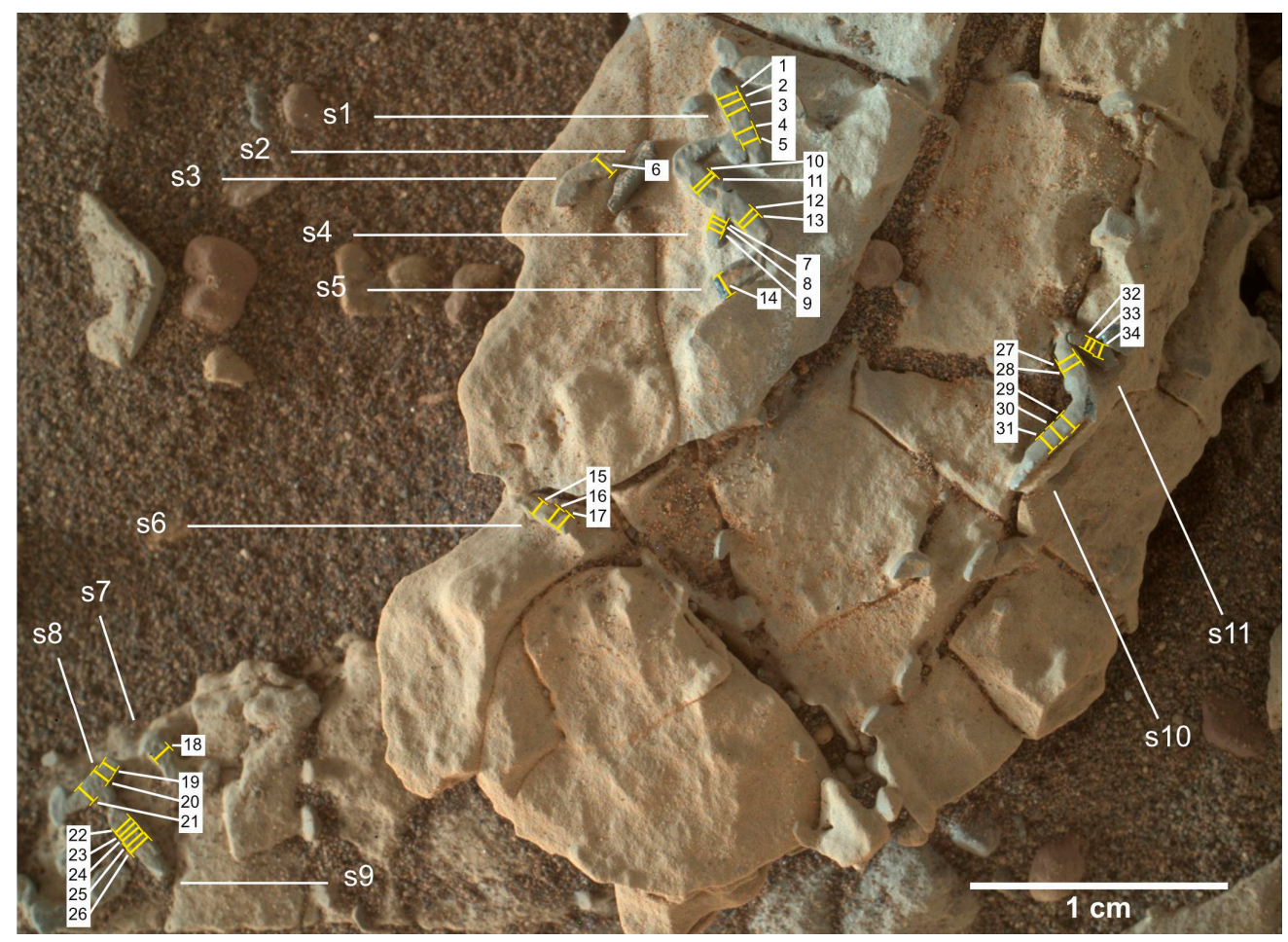

Figure A1. Width analysis map. Numbers 1-34 refer to the measurement ID in Table A1.

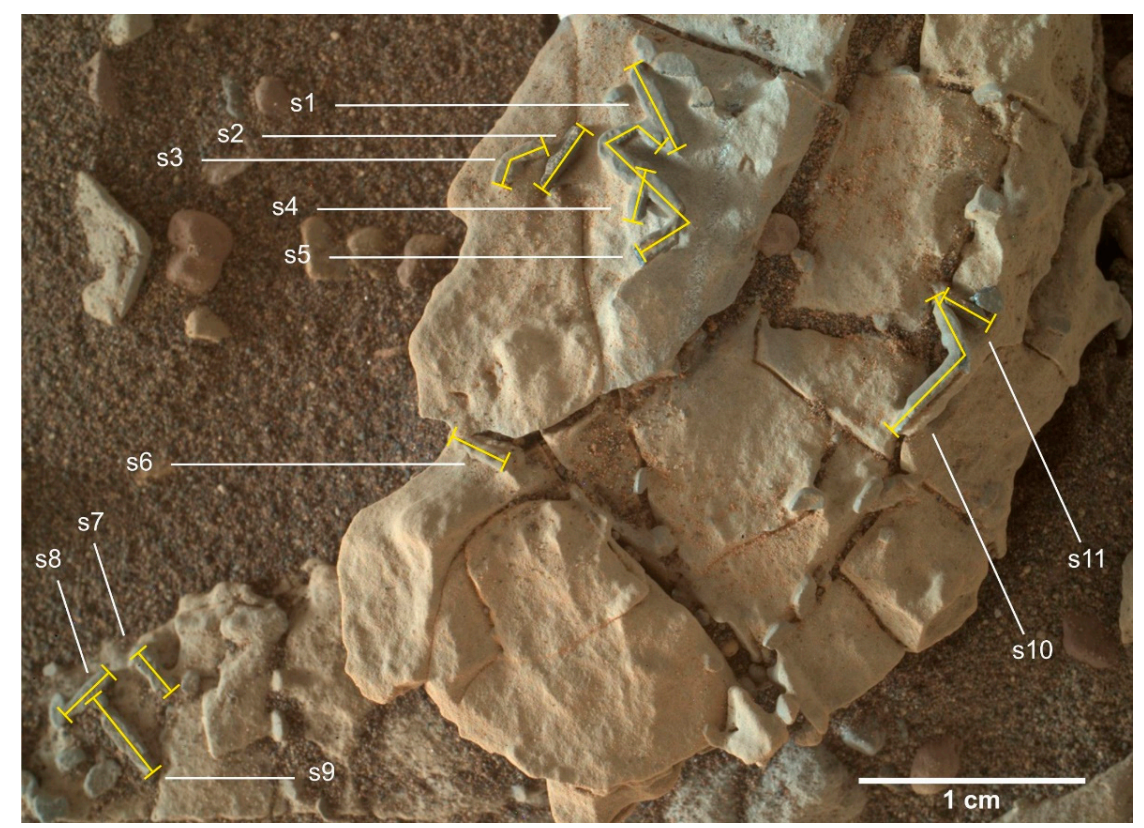

Figure A2. Length analysis map. 


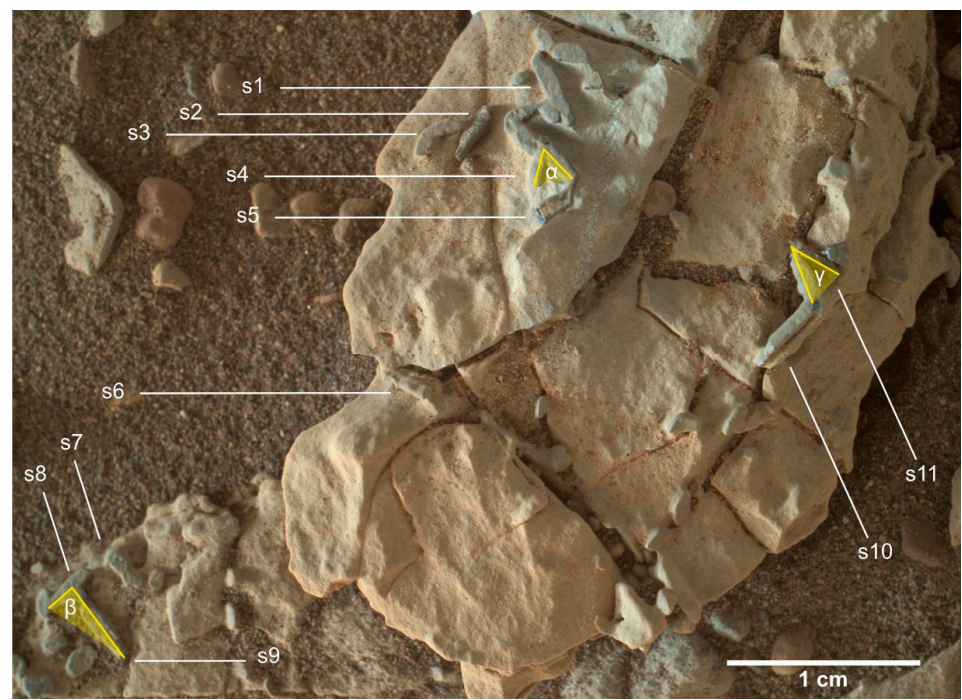

Figure A3. Angle analysis map.

Table A1. (following page). Width measures of the stick-like structures from Vera Rubin Ridge, Mars. See Figure A1 for location of measurements.

\begin{tabular}{|c|c|c|}
\hline Measurement ID & Measured Specimen & Width $(\mathrm{cm})$ \\
\hline 1 & s1 & 0.08 \\
\hline 2 & s1 & 0.08 \\
\hline 3 & s1 & 0.08 \\
\hline 4 & s1 & 0.07 \\
\hline 5 & s1 & 0.06 \\
\hline 6 & s3 & 0.09 \\
\hline 7 & s4 & 0.07 \\
\hline 8 & s4 & 0.06 \\
\hline 9 & s4 & 0.06 \\
\hline 10 & s5 & 0.09 \\
\hline 11 & s5 & 0.09 \\
\hline 12 & s5 & 0.08 \\
\hline 13 & s5 & 0.08 \\
\hline 14 & s5 & 0.09 \\
\hline 15 & s6 & 0.06 \\
\hline 16 & s6 & 0.06 \\
\hline 17 & s6 & 0.07 \\
\hline 18 & s7 & 0.07 \\
\hline 19 & s8 & 0.05 \\
\hline 20 & s8 & 0.07 \\
\hline 21 & s8 & 0.07 \\
\hline 22 & s9 & 0.08 \\
\hline 23 & s9 & 0.08 \\
\hline 26 & s9 & 0.08 \\
\hline 24 & s9 & 0.08 \\
\hline 27 & s10 & 0.07 \\
\hline 25 & s9 & 0.08 \\
\hline 28 & s10 & 0.08 \\
\hline 29 & s10 & 0.07 \\
\hline 30 & s10 & 0.07 \\
\hline 31 & s10 & 0.07 \\
\hline 32 & s11 & 0.04 \\
\hline 33 & s11 & 0.05 \\
\hline \multirow[t]{4}{*}{34} & s11 & 0.04 \\
\hline & Mean & 0.07 \\
\hline & Min & 0.04 \\
\hline & Max & 0.09 \\
\hline
\end{tabular}


Table A2. Length measures of the stick-like structures from Vera Rubin Ridge, Mars. See Figure A2 for location of measurements.

\begin{tabular}{cc}
\hline Specimen & Length $(\mathbf{c m})$ \\
\hline s1 & 0.40 \\
s2 & 0.30 \\
s3 & 0.26 \\
s4 & 0.22 \\
s5 & 1.05 \\
s6 & 0.25 \\
s7 & 0.24 \\
s8 & 0.26 \\
s9 & 0.43 \\
s10 & 0.81 \\
s11 & 0.23 \\
Mean & 0.40 \\
Min & 0.22 \\
Max & 1.05 \\
\hline
\end{tabular}

Table A3. Angle measures of the stick-like structures from Vera Rubin Ridge, Mars. See Figure A3 for location of measurements.

\begin{tabular}{ccc}
\hline Angle ID & Rays of the Angle & Angle $\left(^{\circ}\right.$ ) \\
\hline$\alpha$ & s4-s5 & 63.1 \\
$\beta$ & s8-s9 & 85.6 \\
$\gamma$ & s10-s11 & 39.8 \\
& Mean & 63.1 \\
Min & 39.8 \\
& Max & 85.6 \\
\hline
\end{tabular}

\section{References}

1. Asikainen, C.A.; Francus, P.; Brigham-Grette, J. Sedimentology, clay mineralogy and grain-size as indicators of $65 \mathrm{ka}$ of climate change from El'gygytgyn Crater Lake, Northeastern Siberia. J. Paleolimnol. 2007, 37, 105-122. [CrossRef]

2. Scott, J.J.; Renaut, R.W.; Buatois, L.A.; Owen, R.B. Biogenic structures in exhumed surfaces around saline lakes: An example from Lake Bogoria, Kenya Rift Valley. Palaeogeogr. Palaeoclimatol. Palaeoecol. 2009, 272, 176-198. [CrossRef]

3. Greicius, T. Stick-Shape, Rice-Size Features on Martian Rock "Haroldswick". Available online: https: //www.nasa.gov/image-feature/jpl/pia22213/stick-shape-rice-size-features-on-martian-rock-haroldswick (accessed on 8 October 2019).

4. DiGregorio, B. Ichnological evidence for bioturbation in an ancient lake at Vera Rubin Ridge, Gale Crater, Mars. In Proceedings of the 3rd International Convention on Geosciences and Remote Sensing, Ottawa, ON, Canada, 19-20 October 2018; pp. 1-7.

5. Howell, E. No, Those Aren't Animal Tracks on Mars. Available online: https://www.space.com/39894-marsrock-features-not-animal-tracks.html (accessed on 8 October 2019).

6. Howell, E. Did Crystals from Ancient Lakes on Mars Form These Tiny, Weird Things? Available online: https: //www.space.com/39687-ancient-mars-lakes-made-weird-crystal-features.html (accessed on 8 October 2019).

7. David, L. Curiosity Rover Spots Weird Tube-Like Structures on Mars. Available online: https://www.space. com/39294-mars-rover-curiosity-weird-tube-structures.html (accessed on 8 October 2019).

8. Frydenvang, J.; Mangold, N.; Wiens, R.C.; Fraeman, A.A.; Edgar, L.A.; Fedo, C.; L'Haridon, J.; Gupta, S.; Grotzinger, J.P.; Bedford, C.; et al. The role of large-scale diagenesis in the formation of Vera Rubin Ridge in Gale crater, Mars, as implied by ChemCam observations. In Proceedings of the 50th Lunar and Planetary Science Conference, The Woodlands, TX, USA, 18-22 March 2019; Volume 2019; LPI Contribution No. 2132. 
9. Fraeman, A.A.; Arvidson, R.E.; Catalano, J.G.; Grotzinger, J.P.; Morris, R.V.; Murchie, S.L.; Stack, K.M.; Humm, D.C.; McGovern, J.A.A.; Seelos, F.P.P.; et al. A hematite-bearing layer in Gale crater, Mars: Mapping and implications for past aqueous conditions. Geology 2013, 41, 1103-1106. [CrossRef]

10. L'Haridon, J.; Mangold, N.; Rapin, W.; Cousin, A.; Johnson, J.R.; Fraeman, A.A.; Meslin, P.-Y.; Gasnault, O.; Maurice, S.; Wiens, R. Diagenetic iron enrichments observed by ChemCam on Vera Rubin Ridge, Gale Crater, Mars. In Proceedings of the 49th Lunar and Planetary Science Conference 2018, The Woodlands, TX, USA, 19-23 March 2018; LPI Contribution No. 2083.

11. Heydari, E.; Parker, T.J.; Calef, F.J.; Schroeder, J.F.; Van Beek, J.; Rowland, S.K.; Fairen, A.G. Characteristics and the origin of the Vera Rubin Ridge, Gale Crater, Mars. In Proceedings of the 49th Lunar and Planetary Science Conference 2018, The Woodlands, TX, USA, 19-23 March 2018; LPI Contrib No. 2083.

12. Frydenvang, J.; Mangold, N.; Wiens, R.C.; Fraeman, A.A.; Edgar, L.A.; Fedo, C.M.; L'Haridon, J.; Bedford, C.C.; Gupta, S.; Grotzinger, J.P.; et al. The chemostratigraphy of the lacustrine Murray formation in Gale crater, Mars, and evidence for large-scale diagenesis in Vera Rubin ridge bedrock as implied by ChemCam observations. In Proceedings of the Ninth International Conference on Mars 2019, Pasadena, CA, USA, 22-25 July 2019; LPI Contrib. No. 2089.

13. Williams, A.J.; Sumner, D.Y.; Alpers, C.N.; Karunatillake, S.; Hofmann, B.A. Preserved Filamentous Microbial Biosignatures in the Brick Flat Gossan, Iron Mountain, California. Astrobiology 2015, 15, 637-668. [CrossRef] [PubMed]

14. Stein, N.; Grotzinger, J.P.; Schieber, J.; Mangold, N.; Hallet, B.; Newsom, H.; Stack, K.M.; Berger, J.A.; Thompson, L.; Siebach, K.L.; et al. Desiccation cracks provide evidence of lake drying on Mars, Sutton Island member, Murray formation, Gale Crater. Geology 2018, 46, 515-518. [CrossRef]

15. Rampe, E.B.; Ming, D.W.; Blake, D.F.; Bristow, T.F.; Chipera, S.J.; Grotzinger, J.P.; Morris, R.V.; Morrison, S.M.; Vaniman, D.T.; Yen, A.S.; et al. Mineralogy of an ancient lacustrine mudstone succession from the Murray formation, Gale crater, Mars. Earth Planet. Sci. Lett. 2017, 471, 172-185. [CrossRef]

16. Grotzinger, J.P.; Sumner, D.Y.; Kah, L.C.; Stack, K.; Gupta, S.; Edgar, L.; Rubin, D.; Lewis, K.; Schieber, J.; Mangold, N.; et al. A habitable fluvio-lacustrine environment at Yellowknife Bay, Gale Crater, Mars. Science 2014, 343, 1242777. [CrossRef]

17. Grotzinger, J.P.; Gupta, S.; Malin, M.C.; Rubin, D.M.; Schieber, J.; Siebach, K.; Sumner, D.Y.; Stack, K.M.; Vasavada, A.R.; Arvidson, R.E.; et al. Deposition, exhumation, and paleoclimate of an ancient lake deposit, Gale crater, Mars. Science 2015, 350, aac7575. [CrossRef] [PubMed]

18. Hurowitz, J.A.; Grotzinger, J.P.; Fischer, W.W.; McLennan, S.M.; Milliken, R.E.; Stein, N.; Vasavada, A.R.; Blake, D.F.; Dehouck, E.; Eigenbrode, J.L.; et al. Redox stratification of an ancient lake in Gale crater, Mars. Science 2017, 356, eaah6849. [CrossRef] [PubMed]

19. Dohm, J.M.; Ferris, J.C.; Baker, V.R.; Anderson, R.C.; Hare, T.M.; Strom, R.G.; Barlow, N.G.; Tanaka, K.L.; Klemaszewski, J.E.; Scott, D.H. Ancient drainage basin of the Tharsis region, Mars: Potential source for outflow channel systems and putative oceans or paleolakes. J. Geophys. Res. Planets 2001, 106, 32943-32958. [CrossRef]

20. Edgar, L.A.; Fraeman, A.A.; Gupta, S.; Fedo, C.M.; Grotzinger, J.P.; Stack, K.M.; Bennett, K.A.; Sun, V.Z.; Banham, S.G.; Stein, N.T.; et al. Sedimentology and stratigraphy observed at Vera Rubin Ridge by the Mars science laboratory Curiosity Rover. In Proceedings of the 49th Lunar and Planetary Science Conference 2018, The Woodlands, TX, USA, 19-23 March 2018; Volume 2018, pp. 5-6.

21. Yingst, R.A.; Edgett, K.S.; Kennedy, M.R.; Krezoski, G.M.; McBride, M.J.; Minitti, M.E.; Ravine, M.A.; Williams, R.M.E. MAHLI on Mars: Lessons learned operating a geoscience camera on a landed payload robotic arm. Geosci. Instrum. Methods Data Syst. 2016, 5, 205-217. [CrossRef]

22. Grotzinger, J.; Bell, I.; Herkenhoff, K.; Johnson, J.; Knoll, A.; McCartney, E.; McLennan, S.; Metz, J.; Moore, J.; Squyres, S.; et al. Sedimentary textures formed by aqueous processes, Erebus crater Meridiani Planum, Mars. Geology 2006, 34, 1085-1088. [CrossRef]

23. McMahon, S.; van S. Hood, A.; McIlroy, D. The origin and occurrence of subaqueous sedimentary cracks. In Earth System Evolution and Early Life: A Celebration of the Work of Martin Brasier. Special Publications 448; Brasier, A.T., McIlroy, D., McLoughlin, N., Eds.; Geological Society: London, UK, 2017; pp. 285-309.

24. Harazim, D.; Callow, R.H.T.; Mcilroy, D. Microbial mats implicated in the generation of intrastratal shrinkage ('synaeresis') cracks. Sedimentology 2013, 60, 1621-1638. [CrossRef] 
25. Siebach, K.L.; Grotzinger, J.P.; Kah, L.C.; Stack, K.M.; Malin, M.; Léveillé, R.; Sumner, D.Y. Subaqueous shrinkage cracks in the Sheepbed mudstone: Implications for early fluid diagenesis, Gale crater, Mars. J. Geophys. Res. Planets 2014, 119, 1597-1613. [CrossRef]

26. Jensen, S.; Droser, M.L.; Gehling, J.G. Trace fossil preservation and the early evolution of animals. Palaeogeogr. Palaeoclimatol. Palaeoecol. 2005, 220, 19-29. [CrossRef]

27. Noffke, N. Ancient Sedimentary Structures in the <3.7 Ga Gillespie Lake Member, Mars, That Resemble Macroscopic Morphology, Spatial Associations, and Temporal Succession in Terrestrial Microbialites. Astrobiology 2015, 15, 169-192.

28. Al-Youssef, M. Gypsum Crystals Formation and Habits, Umm Said Sabkha, Qatar. In Sabkha Ecosystems Volume IV: Cash Crop Halophyte and Biodiversity Conservation. Part of the Tasks for Vegetation Science Book Series (TAVS, Volume 47); Khan, M.A., Böer, B., Öztürk, M., Zahran, T., Abdessalaam, A., Clüsener-Godt, M., Gul, B., Eds.; Springer: Berlin, Germany, 2014; pp. 23-54.

29. Klein, C.; Philpotts, A.R. Earth Materials: Introduction to Mineralogy and Petrology; Cambridge University Press: Cambridge, UK, 2013.

30. Becker, A. Facies development of the Badenian (Middle Miocene) gypsum deposits in the Racławice area (Miechów Upland, southern Poland). Ann. Soc. Geol. Pol. 2016, 75, 111-120.

31. Babel, M.; Bogucki, A. The Badenian evaporite basin of the northern Carpathian Foredeep as a model of a meromictic selenite basin. In Evaporites Through Space and Time. Geological Society of London Special Publications; Schreiber, B., Lugli, S., Babel, M., Eds.; The Geological Society of London: London, UK, 2007; Volume 285, pp. 219-246.

32. Benison, K.C.; Karmanocky, F.J., III. Could microorganisms be preserved in Mars gypsum? Insights from terrestrial examples. Geology 2014, 42, 615-618. [CrossRef]

33. Rinaudo, C.; Franchini-angela, M.; Boistelle, R. Curvature of gypsum crystals induced by growth in the presence of impurities. Mineral. Mag. 1989, 53, 479-482. [CrossRef]

34. Seilacher, A.; Meschede, M.; Bolton, E.W.; Luginsland, H. Precambrian "fossil" Vermiforma is a tectograph. Geology 2000, 28, 235-238. [CrossRef]

35. Mettraux, M.; Homewood, P.W.; Kwarteng, A.Y.; Mattner, J. Coastal and continental sabkhas of Barr Al Hikman, Sultanate of Oman. In Quaternary Carbonate and Evaporite Sedimentary Facies and Their Ancient Analogues: A Tribute to Douglas James Shearman; The International Association of Sedimentologists Special Publications; Wiley-Blackwell: Hoboken, NJ, USA, 2011; Volume 43, pp. 183-204. ISBN 9781444339109.

36. Otálora, F.; Mazurier, A.; Garcia-Ruiz, J.M.; Kranendonk, M.J.; Van Kotopoulou, E.; El Albani, A.; Garridoa, C.J. A crystallographic study of crystalline casts and pseudomorphs from the 3.5 Ga Dresser Formation, Pilbara Craton (Australia). J. Appl. Crystallogr. 2018, 51, 1-9. [CrossRef] [PubMed]

37. Vickers, M.; Watkinson, M.; Price, G.D.; Jerrett, R. An improved model for the ikaite-glendonite transformation: Evidence from the Lower Cretaceous of Spitsbergen, Svalbard. Nor. J. Geol. 2018, 98, 1-15. [CrossRef]

38. Minter, N.J.; Krainer, K.; Lucas, S.G.; Braddy, S.J.; Hunt, A.P. Palaeoecology of an Early Permian playa lake trace fossil assemblage from Castle Peak, Texas, USA. Palaeogeogr. Palaeoclimatol. Palaeoecol. 2007, 246, 390-423. [CrossRef]

39. Baucon, A.; Venturini, C.; Neto de Carvalho, C.; Felletti, F.; Muttoni, G. Behaviours mapped by new geographies: Ichnonetwork analysis of the Val Dolce Formation (lower Permian; Italy-Austria). Geosphere 2015, 11, 744-776. [CrossRef]

40. Baucon, A.; Carvalho, C. From the river to the sea: Pramollo, a new ichnolagerstätte from the Carnic Alps. Stud. Trent. Sci. Nat. Acta Geol. 2008, 83, 87-114.

41. Kowalewski, M.; Demko, T.M. Trace fossils and population paleoecology: Comparative analysis of size-frequency distributions derived from burrows. Lethaia 1996, 29, 113-124. [CrossRef]

42. Mángano, M.G.; Carmona, N.; Buatois, L.; Muñiz Guinea, F. A New Ichnospecies of Arthrophycus from the Upper Cambrian-Lower Tremadocian of Northwest Argentina: Implications for the Arthrophycid Lineage and Potential in Ichnostratigraphy. Ichnos 2005, 12, 179-190. [CrossRef]

43. Monaco, P. Bulbichnus giornii n. ichnogen. and n. ichnosp.: A deep-water domichnion-praedichnion made by an eunicid polychaete (Marnoso-Arenacea Formation, Miocene, Northern Apennines, central Italy). Boll. Della Soc. Paleontol. Ital. 2016, 55, 172. 
44. Neto de Carvalho, C.; Fernandes, A.C.S.; Borghi, L. Diferenciação das icnoespécies e variantes de Arthrophycus e sua utilização problemática em Icnoestratigrafia: O resultado de homoplasias comportamentais entre anelídeos e artrópodes? [Distinction between Arthrophycus ichnospecies and variants and their d. Rev. Española Paleontol. 2003, 18, 221-228.

45. Plotnick, R.E. Behavioral biology of trace fossils. Paleobiology 2012, 38, 459-473. [CrossRef]

46. Sims, D.W.; Reynolds, A.M.; Humphries, N.E.; Southall, E.J.; Wearmouth, V.J.; Metcalfe, B.; Twitchett, R.J. Hierarchical random walks in trace fossils and the origin of optimal search behavior. Proc. Natl. Acad. Sci. USA 2014, 111, 11073-11078. [CrossRef] [PubMed]

47. Raup, D.M.; Seilacher, A. Fossil foraging behavior: Computer Simulation. Science 1969, 166, 994-995. [CrossRef] [PubMed]

48. Berra, F.; Felletti, F. Syndepositional tectonics recorded by soft-sediment deformation and liquefaction structures (continental Lower Permian sediments, Southern Alps, Northern Italy): Stratigraphic significance. Sediment. Geol. 2011, 235, 249-263. [CrossRef]

49. Lowe, D.R.; LoPiccolo, R.D. The characteristics and origins of dish and pillar structures. J. Sediment. Res. 1974, 44, 484-501.

50. Laubach, S.E.; Schultz-Ela, D.D.; Tyler, R. Differential compaction of interbedded sandstone and coal. Geol. Soc. Lond. Spec. Publ. 1999, 169, 51-60. [CrossRef]

51. Virtasalo, J.J.; Löwemark, L.; Papunen, H.; Kotilainen, A.T.; Whitehouse, M.J. Pyritic and baritic burrows and microbial filaments in postglacial lacustrine clays in the northern Baltic Sea. J. Geol. Soc. Lond. 2010, 167, 1185-1198. [CrossRef]

52. Virtasalo, J.J.; Whitehouse, M.J.; Kotilainen, A.T. Iron isotope heterogeneity in pyrite fillings of Holocene worm burrows. Geology 2013, 41, 39-42. [CrossRef]

53. Baucon, A.; Ronchi, A.; Felletti, F.; Neto de Carvalho, C. Evolution of Crustaceans at the edge of the end-Permian crisis: Ichnonetwork analysis of the fluvial succession of Nurra (Permian-Triassic, Sardinia, Italy). Palaeogeogr. Palaeoclimatol. Palaeoecol. 2014, 410, 74-103. [CrossRef]

54. Gingras, M.K.; MacEachern, J.A.; Dashtgard, S.E. Process ichnology and the elucidation of physico-chemical stress. Sediment. Geol. 2011, 237, 115-134. [CrossRef]

55. Baucon, A.; Neto de Carvalho, C. Stars of the aftermath: Asteriacites beds from the Lower Triassic of the Carnic Alps (Werfen Formation, Sauris di Sopra), Italy. Palaios 2016, 31, 161-176. [CrossRef]

56. Wacey, D. Early Life on Earth: A Practical Guide; Springer Science + Business Media B.V.: Berlin, Germany, 2009.

57. Baumann, L.M.F.; Birgel, D.; Wagreich, M.; Peckmann, J. Microbially-driven formation of Cenozoic siderite and calcite concretions from eastern Austria. Austrian J. Earth Sci. 2016, 109. [CrossRef]

58. Brown, B.J.; Farrow, G.E. Recent dolomitic concretions of crustacean burrow origin from Loch Sunart, west coast of Scotland. J. Sediment. Res. 1978, 48, 825-833.

59. Cox, T.L.; Oze, C.; Horton, T.W. Iron concretions within a highly altered unit of the Berlins Porphyry, New Zealand: An abiotic or biotic story? Mineral. Petrol. 2017, 111, 173-181. [CrossRef]

60. Nachon, M.; Mangold, N.; Forni, O.; Kah, L.C.; Cousin, A.; Wiens, R.C.; Anderson, R.; Blaney, D.; Blank, J.G.; Calef, F.; et al. Chemistry of diagenetic features analyzed by ChemCam at Pahrump Hills, Gale crater, Mars. Icarus 2017, 281, 121-136. [CrossRef]

61. Brasier, M.D.; Wacey, D. Fossils and astrobiology: New protocols for cell evolution in deep time. Int. J. Astrobiol. 2012, 11, 217-228. [CrossRef]

62. Brasier, M.D. Towards a Null Hypothesis for Stromatolites. In Earliest Life on Earth: Habitats, Environments and Methods of Detection; Golding, S.D., Glikson, M., Eds.; Springer Science + Business Media B.V.: Dordecht, The Netherlands, 2011; pp. 115-125. ISBN 9789048187942.

63. Zahnle, K.; Freedman, R.S.; Catling, D.C. Is there methane on Mars? Icarus 2011, 212, 493-503. [CrossRef]

64. Mustard, J.F.; Adler, M.; Allwood, A.; Bass, D.S.; Beaty, D.W.; Bell, J.F., III; Brinckerhoff, W.B.; Carr, M.; Marais, D.J.D.; Drake, B.; et al. Report of the Mars 2020 Science Definition Team. Available online: http://mepag.jpl.nasa.gov/reports/MEP/Mars_2020_SDT_Report_Final.pdf (accessed on 21 January 2020).

65. Ruff, S.W.; Farmer, J.D. Silica deposits on Mars with features resembling hot spring biosignatures at El Tatio in Chile. Nat. Commun. 2016, 7, 13554. [CrossRef]

66. Jensen, S.; Droser, M.L.; Gehling, J.G. A Critical Look at the Ediacaran Trace Fossil Record. In Neoproterozoic Geobiology and Paleobiology; Xiao, S., Kaufman, A.J., Eds.; Springer: Dordecht, The Netherlands, 2006; pp. 115-157. 
67. Knaust, D.; Hauschke, N. Trace fossils versus pseudofossils in Lower Triassic playa deposits, Germany. Palaeogeogr. Palaeoclimatol. Palaeoecol. 2004, 215, 87-97.

68. Neto de Carvalho, C.; Couto, H.; Figueiredo, M.V.; Baucon, A. Microbial-related biogenic structures from the Middle Ordovician slates of Canelas (northern Portugal). Comun. Geológicas 2016, 103, $23-37$.

69. El Albani, A.; Mangano, M.G.; Buatois, L.A.; Bengtson, S.; Riboulleau, A.; Bekker, A.; Konhauser, K.; Lyons, T.; Rollion-Bard, C.; Bankole, O.; et al. Organism motility in an oxygenated shallow-marine. Proc. Natl. Acad. Sci. USA 2018, 116, 3431-3436. [CrossRef]

70. Baucon, A.; Neto de Carvalho, C.; Barbieri, R.; Bernardini, F.; Cardini, A.; Cavalazzi, B.; Celani, A.; Felletti, F.; Ferretti, A.; Schoenlaub, H.P.; et al. Organism-substrate interactions and astrobiology: Potential, models, methods. Earth Sci. Rev. 2016, 171, 141-180. [CrossRef]

71. Seilacher, A.; Buatois, L.A.; Mángano, G. Trace fossils in the Ediacaran-Cambrian transition: Behavioral diversification, ecological turnover and environmental shift. Palaeogeogr. Palaeoclimatol. Palaeoecol. 2005, 227, 323-356. [CrossRef]

72. Neto de Carvalho, C.; Rodrigues, N.P.C.; Viegas, P.A.; Baucon, A.; Santos, V.F. Patterns of occurrence and distribution of crustacean ichnofossils in the Lower Jurassic-Upper Cretaceous of Atlantic occidental margin basins, Portugal. Acta Geol. Pol. 2010, 60, 19-28.

73. Neto De Carvalho, C.; Baucon, A. Giant trilobite burrows and their paleobiological significance (Lower-to-Middle Ordovician from Penha Garcia, Portugal). Comun. Geol. 2016, 103, 71-82.

74. Neto De Carvalho, C.; Baucon, A.; Gonçalves, D. Daedalus mega-ichnosite from the Muradal Mountain (Naturtejo Global Geopark, Central Portugal): Between the Agronomic Revolution and the Ordovician Radiation. Comun. Geol. 2016, 103, 59-70.

75. Hollocher, K. A Pictorial Guide to Metamorphic Rocks in the Field; CRC Press/Balkema: Leiden, The Netherlands, 2014.

76. Nutman, A.P.; Bennett, V.C.; Friend, C.R.L.; Van Kranendonk, M.J.; Chivas, A.R. Rapid emergence of life shown by discovery of 3,700-million-year-old microbial structures. Nature 2016, 1, 1-12. [CrossRef]

77. Chen, Z.; Chen, X.; Zhou, C.; Yuan, X.; Xiao, S. Late Ediacaran trackways produced by bilaterian animals with paired appendages. Sci. Adv. 2018, 4,1-8. [CrossRef]

78. Savrda, C.E. Taphonomy of trace fossils. In Trace Fossils. Concepts, Problems, Prospects; Miller, W., Ed.; Elsevier: Amsterdam, The Netherlands, 2007; pp. 92-109.

79. Seike, K.; Yanagishima, S.I.; Nara, M.; Sasaki, T. Large Macaronichnus in modern shoreface sediments: Identification of the producer, the mode of formation, and paleoenvironmental implications. Palaeogeogr. Palaeoclimatol. Palaeoecol. 2011, 311, 224-229. [CrossRef]

80. Crippa, G.; Baucon, A.; Felletti, F.; Raineri, G.; Scarponi, D. A multidisciplinary study of ecosystem evolution through early Pleistocene climate change from the marine Arda River section, Italy. Quat. Res. 2018, 89, 533-562. [CrossRef]

81. De Carvalho, C.N.; Pereira, B.; Klompmaker, A.; Baucon, A.; Moita, J.A.; Pereira, P. Running crabs, walking crinoids, grazing gastropods: Behavioral diversity and evolutionary implications of the Cabeço da Ladeira Lagerstätte (Middle Jurassic, Portugal). Comun. Geol. 2016, 103, 39-54.

82. Vallon, L.H.; Rindsberg, A.K.; Bromley, R.G. An updated classification of animal behaviour preserved in substrates. Geodin. Acta 2016, 28, 5-20. [CrossRef]

(C) 2020 by the authors. Licensee MDPI, Basel, Switzerland. This article is an open access article distributed under the terms and conditions of the Creative Commons Attribution (CC BY) license (http://creativecommons.org/licenses/by/4.0/). 